\title{
Translation Equivalences of Islamic Terms in the Novel (The Land of Five Towers 'Negeri Lima Menara')
}

\author{
Erlina Zulkifli Mahmud, Bima Bayusena, Ratna Erika Mawarrani
}

Faculty of Cultural Sciences, Universitas Padjadjaran, Jatinangor, Indonesia

\section{Email address:}

erlina@unpad.ac.id (E.Z. Mahmud), bima.bayusena@gmail.com (B. Bayusena), Ratna.erika@unpad.ac.id (R. E. Mawarrani)

\section{To cite this article:}

Erlina Zulkifli Mahmud, Bima Bayusena, Ratna Erika Mawarrani. Translation Equivalences of Islamic Terms in the Novel (The Land of Five Towers 'Negeri Lima Menara'). International Journal of Applied Linguistics and Translation. Vol. 4, No. 2, 2018, pp. 31-39. doi: $10.11648 /$ j.ijalt.20180402.12

Received: July 22, 2018; Accepted: August 29, 2018; Published: September 27, 2018

\begin{abstract}
The occurrence of Islamic terms in the novel Negeri Lima Menara 'The Land of Five Towers' is related to its theme; the life in a pesantren, an Islamic Boarding School. How students there perform their obligation in their daily lives as Moslems and how they give their best effort to pass all the subjects, all involve terms related to Islam. The Islamic terms used in this research are limited to those which deal with praying and also about the Holy Quran. Mostly the terms of this field are used repeatedly in the source language text. And those which are used for this research is only the same terms used repeatedly. The meaning of the Islamic terms in the source language text is described and compared with the meaning of their equivalences in the target language text, then the equivalences are reviewed using the techniques of translation given by Molina and Albir (2002). What equivalences chosen in the target language text, whether they are "equal-valued" become the object of this research. This study identifies techniques of translation tend to be used; whether the same Islamic terms which are used repeatedly in the text apply the same technique of translation and whether they have the same equivalence or not. The results show that some similar terms used repeatedly in the text are translated using different techniques and having different equivalences, some others are translated using the same techniques but having different equivalences, and there is one which is translated using the same technique and having the same equivalence. The most frequent translation technique used is borrowing.
\end{abstract}

Keywords: Islamic Terms, 'The Land of Five Towers', Equivalences, Molina and Albir's Translation Techniques

\section{Introduction}

A research about Indonesian literary works such as novels which have been translated into English has been initiated since several years ago. The availability of the data source has become relatively easy to find. Before 2015 it could be said that there were almost no Indonesian novels displayed together with their translated works in bookstores as the fact is that there were no Indonesian novels translated into English or other foreign languages and if there was any, the number was very limited. Thanks to Frankfurt Book Fair 2015 which has given a great opportunity to Indonesia to become the invited host of that event by which hundreds of Indonesian novels needed to be translated into foreign languages including English. This really has given positive effects to Indonesia and one of them is to open a wide range of research especially on Translation Studies. The research may come up with findings that can be used as a medium to elaborate, to strengthen, to confirm or even to clarify the information given in the source language text.

Negeri Lima Menara is a novel written by Ahmad Fuadi. $\mathrm{He}$ is an Indonesian writer, a novelist and a social entrepreneur journalist. This novel has won several awards, one of them is the 2010 Favorite Fiction Writer and Book from the Indonesian Readers Awards. The novel is about the life in pesantren, an Islamic boarding school, so there are Islamic terms frequently involved in it. The novel is translated into 'The Land of Five Towers' by Angie Kilbane, an American lady. She has translated some Indonesian novels including Laskar Pelangi 'Rainbow Troops'. Angie is a Fulbright scholar and she got scholarship named Darmasiswa from Indonesian Government in 2008; it was given to her to explore Indonesia more. With this scholarship, she studied 
Indonesian Literature in the University of Indonesia. She had a teaching experience at one of the Islamic schools in Jakarta, The Lazuardi Global Islamic School where she was the only non-Muslim teacher there. Due to this fact, Angie became familiar with Islam.

What happened in the novel is that some similar Islamic terms used repeatedly are translated not always by using the same techniques, sometimes they are translated by using the same technique but having different equivalences, and there are also cases when some Islamic terms have different understandings or concepts. As the author and the translator come from a different culture background, there is always a chance that what the author sees through his novel is differently seen by the translator. Some very specific terms may need a thorough comprehension but unfortunately sometimes there is not any description added in the source language text, either as a footnote or as an embedded clause or phrase unlike the Minangkabau cultural words which are also involved in the novel. The equivalences chosen for the Islamic terms therefore depend completely on the context the translator sees through her own perspectives and understandings.

\section{Literature Review}

The text used as the data source may not be the Holy book but the theme which directly deals with Islam religion requires the same accuracy and the same adequacy. There is a definition of translation that a good translation should fit with the theme of the text; "translating consists in reproducing in the receptor language the closest natural equivalent of the source language message, first in terms of meaning and secondly in terms of style" [1]. All elements of translation ranging from reproducing as what a translator does in rewriting the message in the target language, the terms source language and receptor language, equivalent, message, meaning, and style are there in the definition. The kind of equivalent should be, the closest natural, and adds with more detail that the closest natural equivalent covers both the meaning and the style. Equivalence is as a relation of "equal value" between a start-text segment and a target-text segment [2]. The equal-value refers to a condition where one term or expression in one language has the same value (the same worth or function) when it is transferred to the target language through translation.

How translators do their work to get an equivalence can be called with several different terms. Some translation scholars use the term translation technique and they define the term translation techniques as "procedures to analyze and classify how translation equivalence works" [3]. Newmark (1988) uses the term procedures instead of techniques as opposed to methods (which is for the whole text) to cover what a translator does in finding equivalents of the shorter units such as sentences, phrases, and words [4]. While one of an Indonesian scholar says that "the way how translators find translation equivalence word by word, or phrase by phrase, or sentence by sentence is called translation procedures or translation techniques, or translation strategies" [5]. This means that the three different terms are to refer to the same activity on how translators get equivalents for the target language text.

Dealing with researches about translating Islamic terms and the techniques of translation, there are some previous researches which are taken as references. The closest one to this current research is a research entitled "Translating Strategies of Islamic Terms in Indonesian - English Research Papers". The object of the research is dissertation abstract, the exact number of it is 48 dissertation abstracts, taken from UIN 'State Islamic University' Jakarta repository. It discusses how Islamic terms are translated from Indonesian into English and what strategies are used. The similarity and the difference between the previous research and this research is that both of them have the same objects; Islamic terms in Indonesian language translated into English. The difference is that the previous research studies the equivalences in English by using translation strategies while the current research by using translation techniques. No objection with one of the findings there that the difficulties faced by translators in finding the appropriate words by translating from Quranic, Arabic or Indonesian words into English due to the different concept because of cultural background and points of view, which have to be taken into consideration [6], like for example, Muslims have two different activities, shalat as a verb and $d u^{\prime} a$ as a verb, but they have only one same equivalent in English 'to pray'. This sometimes reveals a problem. This is exactly what happened in The Land of Five Towers 'Negeri Lima Menara'. Angie needs to deal with the different cultures; Indonesian culture involving Islamic terms and American culture where she needs to transfer the same message into equivalences to the readership of the target language text who may not know or have very limited knowledge about Islam.

The second research is entitled "Islamic Religious Terms in English - Translation vs. Transliteration I Ezzeddin Ibrahim and Denys Johnson - Davies' Translation of An Nawawi's Forty Hadiths". The Islamic religious terms used as the object of the research are related to moral and religious laws in Islam called Shari'ah. The religious text of Islam here refers to the Qur'an, the word of Allah and hadiths as the sayings and statements of Prophet Muhammad that are regarded as important tools for understanding the Qur'an. The research focuses more to the choice translator needs to do; either the Islamic religious terms are translated or transliterated. What can be underlined is that one of the findings stated there; "translation is only appropriate when SL and TL words have the same referents and same connotations in SL and TL cultures" [7]. This previous research specifies on the translation work by Ezzeddin Ibrahim and Denys Johnson on hadiths. What is discussed in the current research is a literary work which involves the use of Islamic terms specifically of praying; it is viewed how the term hadiths is translated and how some names of verses and surah in Al-Quran are translated.

The third research which is entitled "An Analysis of the 
Translation Strategies Used to Translate from English into Nyanja, Zambia's "A Simple Guide to the Anti Gender Based Violence (GBV) Act" may not have something to do with the translation of Islamic terms but the application theory used to see how the simple guide is translated from English into Nyanja mostly the same. This research involves Vinay and Darbelnet's translation strategies which have been classified with different name, translation techniques, by Molina and Albir. There are two kinds of translation strategies covers 7 procedures; borrowing, calque, literal translation, transposition, modulation, equivalence and adaptation. These are added by other procedures by the name of supplementary procedures; amplification, deceptive cognates false, explicitation, and generalization. Baker's comment is used to strengthen one of the procedures namely generalization that "generalization is the commonest of strategies for dealing with many types of non-equivalence at word level" [8]. The difference between this previous research with the current research lies on the complexity of the study. The previous research relates the procedures of translation strategies to the Skopos Theory while this current study just uses the translation techniques given by Molina and Albir (2002).

The fourth research is taken as one of the references due to the fact that it reveals some of the Islamic terms which are also used in the current research. The research is about veiling in Indonesia entitled "The Quest for Indonesian Islam; Contestation and Consensus Concerning Veiling". It is a dissertation thesis submitted for the Degree of Doctor of Philosophy at the Australian National University. This thesis is not about translating Islamic terms but at the beginning, the glossary of Islamic terms which is in Indonesian language is described in English. This can be considered as equivalences in translation. So what is used as the reference is limited only to this beginning section of the thesis as a part of thorough study on various transformation in the practice of veiling which have involved changes in its meaning for Indonesian Muslims. It focuses on the problematic phenomenon regarding the use of veil to Indonesian women from the New Order to the Reform Era [9].

The last research used as reference is entitled "Translation Techniques Revisited: A Dynamic and Functional Approach". It is directly related to this current research as one of the classifications of translation procedures called translation techniques taken from several scholars is taken as the tool to study the equivalences of Islamic terms used in The Land of Five Towers 'Negeri Lima Menara', a novel. A technique is the result of a choice made by a translator, its validity will depend on various questions related to the context, the purpose of the translation, audience expectation, etc" [3]. Dealing with translation techniques, there are some different terms which can be applicable to the same activities, for examples, transference with borrowing and naturalization, generalization with functional equivalent, description with descriptive equivalent and paraphrase, amplification with additions and notes, and reduction with omission.

\section{Translation Techniques by Molina \& Albir (2002)}

The fact that each language in the whole world has its own general characteristics as well as its unique characteristics shows that there cannot be any identical equivalence found in any translation. This allows the action of adding, reducing, substituting, in the process of translating. It means that changes as in grammatical shifts or transpositions and changes as in semantic or pragmatic shifts are not avoidable even when translating Bible or Al-Quran which requires accuracy or adequacy. There are 18 ways under the classification of translation techniques Molina and Albir propose in their journal article (2002). Not all of them are used in the translation of Islamic terms from Indonesian into English in The Land of Five Towers 'Negeri Lima Menara'. Those which are discussed here are the techniques involved in this research. There are only eight of them.

The first technique is called Adaptation. In this technique a ST cultural element is replaced with one from the target culture. This includes cultural equivalent. The second technique is called Amplification "it is a technique to introduce details that are not formulated in the ST (source text): information, explicative paraphrasing, when translating from Arabic (to Spanish) to add the Muslim month of fasting to the noun Ramadan" [3]. The information added is very basic information contained in the word, term or expression. By using this technique the readership of the target language understand the complete information as in Ramadan that it is a month when Muslims do the fasting. When the addition involves linguistic elements, Molina and Albir call this translation technique linguistic amplification.

The fourth technique is called Calque: literal translation of a foreign word or phrase; it can be lexical or structural [3]. Literal translation itself is another technique of translation which can be defined as translating a word or an expression word for word. Then there is borrowing which is exactly the same as other borrowings from other scholars. It is defined as "to take a word or expression straight from another language". Transference and naturalization given by Newmark are parts of borrowing technique.

The next technique is called Description. As its name, this technique is "to replace a term or expression with a description of its form or/and function. This indicates that the term which is translated is not mentioned anymore in the target language, just the description of its form or/and function. Another term for this technique is called descriptive equivalent. Then there is Generalization which is defined as "to use a more general or neutral term. Another term for this is called functional equivalent for this that this common procedure, applied to cultural words, requires the use of a culture-free word, sometimes with a new specific term; it therefore neutralizes or generalizes the SL word; and sometimes adds a particular" [4].

The translation technique dealing with the changing of point of view is also a part of this Molina and Albir's classification. It is called Modulation. This modulation can 
be lexical or structural, e.g., to translate as you are going to have a child, instead of, you are going to be a father. Another example is when the English utterance "Mind your own business" is translated into 'Jangan campuri urusanku' ('Do not interfere with my business.'). There are some changes involved there; from positive into negative, from the word "your" into "mine" [10].

\section{Methodology}

This research involves a descriptive-comparative method which is covered in a qualitative research; "any research whose results are captured in words, images, or nonnumeric symbols" [11]. The major purpose of descriptive research is "description of the state of affairs as it exists at present" [12]. Here, the data of Islamic terms written in Indonesian as the source language text are compared with the data written in
English as the target language text to see what translation phenomena occur; whether the same repeated Islamic terms are translated using the same techniques, whether they have the same equivalences, whether they are seen from different perspectives. By analyzing the two texts, the frequency of each technique of translation used can be identified. What are found in the two texts are then described to reach the major purpose of this overall research.

\section{Discussion}

The data collected from the two texts, the source language text and the target language text are grouped into three parts either used repeatedly or used once; equivalences of Islamic terms relating to praying and equivalences of Islamic terms relating to Al-Quran

\subsection{Equivalences of Islamic Terms Relating to Praying}

Table 1. Insyaa Allah.

\begin{tabular}{llll}
\hline Translation Techniques: Borrowing + Generalization & & \\
\hline No. Source Language & Page & Target Language \\
\hline $\begin{array}{l}\text { 1.a Insyaa Allah, dengan do'a Amak dan Ayah, bisa } \\
\text { lulus ..." }\end{array}$ & 6 & $\begin{array}{l}\text { "Insyaa Allah, God willing, with Amak and Father's prayers, I can } \\
\text { pass." }\end{array}$ \\
$\begin{array}{l}\text { Translation Technique: Borrowing } \\
\text { 1.b Insya Allah kita bisa. }\end{array}$ & 333 & Insya Allah we will make it. \\
\hline
\end{tabular}

The term insyaa Allah is an expression used by Muslims as a closing or opening statement of a praying that nothing in this world can happen without permission from Allah. The situation can be seen from this short dialogue.

A: We'll study together tonight at 8 . Will you come too?

B: Insyaa Allah. I will.

Instead of saying "yes" a Muslim (B) says Insyaa Allah which indicates that the speaker is coming. The term insyaa Allah which is highly recommended to be used daily for Muslims is used to confirm that the speaker's plan to come will be under Allah's will. It is translated into Insyaa Allah, God willing which involves two translation techniques; borrowing and generalization. By using the borrowing technique the term insyaa Allah is put back in the target language text and it is totally the same as written in the source language text. As the readers of the target language may not know the meaning of the term, the translator adds the borrowed term with its meaning 'God willing'. The term
Allah as the name of God in Islam is replaced by the term God. This makes the information is generalized that Insyaa Allah 'God willing' can be for God of other religions not specific Allah, the name of God in Islam. The two equivalences used can be considered equal value; both the form and the function. From the two techniques used together in one context and with the equivalences chosen, it is assumed that the readership of the target language will get a clear understanding of what insyaa Allah or in sha Allah means 'If God wills or God willing'.

The term insyaa Allah used in the next context (1.b) is translated into insyaa Allah again as a borrowing. This time, functional or descriptive equivalence is not added. The translator just uses the borrowing technique with the assumption that the meaning of the term does not need to be restated in the next contexts. By keeping the term in the target language text exactly the same as used in the source language reveals the local color of the source language.

Table 2. Shalat Berjamaah

\begin{tabular}{|c|c|c|c|c|}
\hline No. & Source Language & Page & Target Language & Page \\
\hline \multicolumn{5}{|c|}{ Translation Technique: Modulation } \\
\hline 2.a & $\begin{array}{l}\text { Di sini semua murid shalat berjamaah dan mendalami Al- } \\
\text { Qur'an. }\end{array}$ & 31 & $\begin{array}{l}\text { Here all the students perform the Friday congregational prayer } \\
\text { together and study the Al-Quran. }\end{array}$ & 30 \\
\hline \multicolumn{5}{|c|}{ Translation Technique: Calque } \\
\hline & Bagian tengah kamar tetap kosong untuk kita gunakan tempat & 56 & "The center of the room must remain vacant for us to use for & 53 \\
\hline 2.b & shalat berjamaah setiap kamar, “... & 2 & daily communal prayers in every room," & 2 \\
\hline \multicolumn{5}{|c|}{ Translation Technique: Calque } \\
\hline 2.c & $\begin{array}{l}\text { Pada kenyataannya sarung dipakai selama beberapa jam saja, } \\
\text { ketika shalat berjamaah. }\end{array}$ & 85 & $\begin{array}{l}\text { The fact was, sarongs were only worn for a few hours, during } \\
\text { congregational prayer. }\end{array}$ & 79 \\
\hline
\end{tabular}

There are three kinds of equivalences regarding the translation of the term shalat berjamaah. The term "shalat 
berjamaah" refers to the activity of doing prayers together with others in a mosque or at home or any place which is functional in Islam law to perform prayers. It covers all prayers performed together. Muslims are strongly recommended to perform prayers especially the five obligational prayers together with others especially at a mosque including the Friday prayer obliged for Male Muslims. Initially the term shalat berjamaah as in (2.a) is translated into 'the Friday congregational prayer together'. The word 'Friday' is put there with the assumption that the translator has the knowledge that Muslims come to the mosque on Friday to perform prayer together so she describes the meaning of shalat berjamaah as the Friday congregational prayers together. The word "together" is used in the description to emphasize the meaning that the prayer is done not individually but together. As the superordinate "shalat berjamaah" covers all prayers performed together, and the Friday congregational prayer is just a part of it, the equivalence chosen $n$ (2.a) shows the relation part for the whole. Therefore the translation technique used is modulation.

The term shalat berjamaah in (2.b) is translated differently. The technique used is not modulation anymore, it is calque as the term is translated literally and the form in a phrase, is kept. The term shalat berjamaah is translated into communal prayer which means a prayer which is done together with others in a community; the room mates and it is done in a room not at the mosque. While in (2.c) the term shalat berjamaah is translated into congregational prayer. Congregational here means involving or done by the people who attend religious activities. The context in (2.c) is that the prayer is done together at the mosque in congregation. So the translation technique used in (2.b) and (2.c) is the same, calque, yet the equivalences are different. The translator has a good knowledge about this that she chooses to give different equivalences for the same Islamic term "shalat berjamaah" because she would like the readers of the target language are aware that in a different context the term "shalat berjamaah" has different meaning, different emphasis. The equivalences chosen in $(2 . b, 2 . c)$ can be considered as equal value.

Table 3. Imam.

\begin{tabular}{llcl}
\hline No. $\quad$ Source Language & Page & Target Language \\
\hline $\begin{array}{l}\text { Translation Techniques: Borrowing + Generalization } \\
\text { 3.a Setiap orang akan mendapat giliran menjadi imam. }\end{array}$ & 57 & Everybody will get a turn to become the imam, prayer leader. \\
$\begin{array}{l}\text { Translation Technique: Generalization } \\
\text { 3.b } \quad \text {...seorang kakak penggerak bahasa masuk ke setiap kamar dan } \\
\text { beridir di depan, tepat di sebelah imam } \text { shalat kami tadi. }\end{array}$ & 132 & $\begin{array}{l}\text {... a language patroller upperclassman come into every room } \\
\text { and stood up front, right beside the prayer leader. }\end{array}$ \\
\hline
\end{tabular}

The term imam in general refers to a leader, a Muslim leader, including a prayer leader. In the contexts of (3.a) and (3.b) the term imam is specified to a prayer leader. Initially the term imam is translated using two translation techniques: borrowing and generalization. The borrowing technique is needed to strengthen the equivalence "prayer leader" that the prayer leader is called imam in Islam. As the term imam does not exist in English language, these two techniques used together in translating the term are the best choice. This can inform the readership of the target language text that the prayer leader in Islam (not in other religion) is called imam. The use of the two techniques may present the local color of
Indonesian to the target language text.

The next use of the term imam is translated using one technique only; generalization. As the term imam is not used anymore initiated the existence of the equivalence, prayer leader, the meaning of the prayer leader becomes general. It can be used to refer to any prayer leader not specifically in Islam. The translator chooses this technique with the assumption that the information about the term imam has already been delivered the first time the term imam is used in the text. The fact is that the translator may choose between imam used as a borrowing or a generalization.

Table 4. Subuh.

\begin{tabular}{|c|c|c|c|c|}
\hline & Source Language & Page & Target Language & Page \\
\hline \multicolumn{5}{|c|}{ Translation Technique: Borrowing } \\
\hline 4.a & $\begin{array}{l}\text { Sementara } 2 \text { kali seminggu, setiap selesai Subuh, dalam } \\
\text { suasana temaram... }\end{array}$ & 133 & Also, two times a week, after Subuh, in dim sunlight... & 124 \\
\hline \multicolumn{5}{|c|}{ Translation Technique: Description } \\
\hline 4.b & Sampai pada suatu Jumat, jam 4 subuh, ... & 135 & $\begin{array}{l}\text { After then something happened on Friday, at four o'clock in the } \\
\text { morning. }\end{array}$ & 126 \\
\hline \multicolumn{5}{|c|}{ Translation Technique: Borrowing + Amplification } \\
\hline 4.c & Setelah subuh, aku langsung terjun ke kamar mandi, & 252 & After Subuh prayer, I went straight down to the bathroom.. & 238 \\
\hline \multicolumn{5}{|c|}{ Translation Technique: Literal Translation } \\
\hline 4.d & $\begin{array}{l}\text { Padahal masih satu halaman lagi yang harus ditulis tangan } \\
\text { indah menjelang azan Subuh berkumandang. }\end{array}$ & 296 & $\begin{array}{l}\text { But there was still one more page that had to be written } \\
\text { beautifully by hand before the dawn call to prayer sounded. }\end{array}$ & 277 \\
\hline
\end{tabular}

There are four kinds of equivalences found in the translation of the Islamic term subuh. The term has been used repeatedly in the source language text but it does not always have the same equivalence in the target language text. When it is used with the term prayer, subuh prayer, it is also known as [13] Fajr (Dawn) prayer which starts at dawn when 
morning light first appears in the horizon and continues until the sun rises.

In (4.a) the term subuh refers to prayer. It is translated into English by using borrowing technique. The translator just put the exact word in the target language without any explanation. In (4.b) the term subuh refers to the time, at 4 $\mathrm{AM}$ so it is of equal value when translated into a short description 'in the morning'. The technique used is description as it describes the time. While in (4.c) the term subuh is used to refer to a prayer so the translator adds the word "prayer" (which is not formulated in the source language text) after the borrowed term subuh to explicit its meaning. In that case, there are two translation techniques involved there; borrowing + amplification. By making it from implicit into explicit, it is assumed that the readership of the target language will get the idea of what subuh is. In (4.d) the term subuh is related to the term azan 'a call to prayer'. It is translated literally into 'dawn' as the translator would like the readership know that there is a call to prayer at dawn time. What happened to this term is that in different contexts, it is translated using different techniques with different equivalences.

Table 5. Ashar 'Asr'

\begin{tabular}{|c|c|c|c|c|}
\hline No. & Source Language & Page & Target Language & Page \\
\hline \multicolumn{5}{|c|}{ Translation Technique: Generalization } \\
\hline 5.a & $\begin{array}{l}\text { Aku semakin panik, azan Ashar berkumandang tapi kartuku } \\
\text { masih kosong. }\end{array}$ & 81 & $\begin{array}{l}\text { I grew more panicked, the call to afternoon prayer was already } \\
\text { echoing but my card was still empty. }\end{array}$ & 76 \\
\hline \multicolumn{5}{|c|}{ Translation Technique: Borrowing } \\
\hline $5 . \mathrm{b}$ & $\begin{array}{l}\text { Setelah shalat Ashar, murid-murid berbondong-bondong ke } \\
\text { lapangan sepak bola yang semakin penuh. }\end{array}$ & 278 & After Asr prayer, students flocked to the field... & 262 \\
\hline
\end{tabular}

The term Ashar refers to one of the obligational prayers performed in the afternoon. When it is azan 'a call to prayer', it is translated into "afternoon" which is related to time. The term afternoon in (5.a) has general meaning, the time after mid-day until sunset time, not specifically related to a name of prayer. The translation technique which is used in (5.a) is called generalization. With this equivalence, it is assumed that the readership of the target language text will get the idea that there is a call to prayer in the afternoon.

In (5.b) the term Ashar is directly transferred to the target language, only this time the transference is not total. The term is naturalized into the pronunciation of the target language that it becomes 'Asr'. With the explanation given in (5.a) about the afternoon prayer it is assumed that the readership of the target language will know that the name of the afternoon prayer is Asr.

Table 6. Maghrib.

\begin{tabular}{lll}
\hline No. $\quad$ Source Language & Page & Target Language \\
\hline $\begin{array}{l}\text { Translation Technique: Borrowing } \\
\text { 6.a } \quad \text {..ketika kami masih shalat Maghrib di masjid. }\end{array}$ & 269 & While we prayed Magrib prayer at the mosque. \\
$\begin{array}{l}\text { Translation Techniques: Borrowing + Amplification } \\
\text { 6.b Aku beranjak ke masjid untuk menunaikan Maghrib }\end{array}$ & 313 & I headed to the mosque for Maghrib prayer. \\
\hline
\end{tabular}

The next prayer discussed is Maghrib. It is one of the obligational prayers in Islam which is performed at sunset time. In the target language text the Islamic term Maghrib which is added to the term shalat 'prayer' (6.a) is transferred totally the same using borrowing translation technique. The translator does not bother to give details about the term as the previous context has already shown what Maghrib is and when it is performed and where it is usually performed at the pesantren (Islamic boarding school). In the source language text (6.b) where the term Maghrib is not explicitly related to the word shalat 'prayer', it has an explicit information in its equivalence; Maghrib prayer. It is assumed that the translator would like to emphasize that Maghrib which is going to be done at the mosque is a prayer. The translation techniques used in (6.b) are borrowing (when the term Maghrib is put back in the target language) and amplification (when the detail is not formulated in the source language is explicitly revealed in the target language text).

Table 7. Isya.

\begin{tabular}{|c|c|c|c|c|}
\hline & Source Language & Page & Target Language & Page \\
\hline \multicolumn{5}{|c|}{ Translation Technique: Borrowing } \\
\hline 7.a & Shalat berjamaah, Isya di kamar & 147 & Communal Isya prayer in the room again. & 137 \\
\hline \multicolumn{5}{|c|}{ Translation Technique: Adaptation } \\
\hline 7.b & Sehabis Isya, murid-murid berbondong-bondong memenuhi aula & 48 & After dinner, students filled the hall in droves. & 46 \\
\hline
\end{tabular}

Isya is a name of prayer performed in the evening after Maghrib prayer. In (7.a) the term Isya is related to the term shalat berjamaah 'communal (as it is performed not at a mosque) prayer'. Nothing is changed there; the term Isya is transferred to the target language text exactly the same using borrowing translation technique. While in (7.b) the translator decides to replace the term Isya with a cultural equivalence, 'dinner', the name of meal done in the evening which actually has nothing to do with a prayer in Islam. What can relate the two terms, Isya and dinner is the fact that both activities are done in the evening, exactly after sunset. The translation technique which is used in (7.b) is then called adaptation. 
Table 8. Tahajjud.

\begin{tabular}{|c|c|c|c|c|}
\hline & Source Language & Page & Target Language & Page \\
\hline \multicolumn{5}{|c|}{ Translation Technique: Description } \\
\hline 8.a & $\begin{array}{l}\text { Daftarkan diri kalian kalau ingin dibangunkan shalat Tahajjud } \\
\text { malam ini. }\end{array}$ & 195 & $\begin{array}{l}\text { Sign up if you would like to be woken up for the night prayer } \\
\text { tonight. }\end{array}$ & 183 \\
\hline \multicolumn{5}{|c|}{ Translation Technique: Borrowing + Description } \\
\hline 8.b & $\begin{array}{l}\text { Aku mencanangkan untuk menambah ibadah dengan shalat } \\
\text { sunnat Tahajjud }\end{array}$ & 195 & $\begin{array}{l}\text { I declared that I would add an additional night prayer called } \\
\text { Sunna Tahajjud... }\end{array}$ & 183 \\
\hline \multicolumn{5}{|c|}{ Translation Techniques: Borrowing + Description } \\
\hline & $\begin{array}{l}\text { Alhamdulillah setelah Tahajjud badanku terasa lebih enteng } \\
\text { dan segar }\end{array}$ & 197 & Alhamdulillah after Tahajud, my body felt lighter and fresher. & 185 \\
\hline
\end{tabular}

The Islamic term Tahajjud is used to refer to an optional/voluntary/additional prayer performed late at night usually after midnight. In (8.a) the term Tahajjud is explicitly stated after the term shalat to indicate that it is a name of prayer. It is translated into the night prayer, a brief information by using description translation technique with no borrowing. While in (8.b) the term Tahajjud is related to another Islamic term sunnat. The term sunnat refers to a practice based on Muhammad's words and deeds. It is translated by using two techniques; borrowing as the term sunnat Tahajjud is put back in the target language text with a partial borrowing as the term sunnat is naturalized into "sunna" and the second technique used is description as the translator gives an explanation about what Sunna Tahajjud is. There is a different understanding in the equivalence when the translator says that what is added is the night prayer which is called Sunna Tahajjud. The real message in the source language text is that what is added is the worship (performing five obligational prayers, fasting in Ramadhan month, reciting Al-Quran, conducting other optional/voluntary good things, etc) and Sunna Tahajjud is only a part of ibadah [9]'worship, religious rituals and duties'. While in (8.c) the same term Tahajjud appears without the term shalat 'prayer' and is translated into the same term as in the source language text. The term shalat 'prayer' which should be attached to the term Tahajjud in the source language text is made implicit. It is assumed that the translator does not bother to make the term shalat 'prayer' explicit in the target language as the explicitness of the term has already been explained in (8.a) and (8.b).

\subsection{Equivalences of Islamic Terms Relating to Al-Quran}

Table 9. Hadiths

\begin{tabular}{|c|c|c|c|c|}
\hline No. & Source Language & Page & Target Language & Page \\
\hline \multicolumn{5}{|c|}{ Translation Technique: Modulation } \\
\hline 9.a & Hadits mengatakan Innallaha jamil wahuwa yuhibbul jamal. & $\begin{array}{l}34 \\
1\end{array}$ & $\begin{array}{l}\text { The Prophet Muhammad said: Innallaha jamil wahuwa yuhibbul } \\
\text { jamal. }\end{array}$ & $\begin{array}{l}33 \\
1\end{array}$ \\
\hline Tran & lation Technique: Borrowing & & & \\
\hline $\begin{array}{l}9 . \mathrm{b} \\
\text { Tran }\end{array}$ & $\begin{array}{l}\text { Bacalah Al-Qur'an dan hadits dengan mata hati kalian. } \\
\text { lation Technique: Borrowing }\end{array}$ & 113 & Read Al-Quran and hadiths with your heart's eye. & 106 \\
\hline 9.c & $\begin{array}{l}\text { Hadits adalah segala sabda dan perbuatan Nabi Muhammad } \\
\text { selama beliau menjadi Rasulallah. }\end{array}$ & 274 & $\begin{array}{l}\text { Hadiths are the words and deeds of the Prophet Muhammad in } \\
\text { his time as the Messenger of Allah. }\end{array}$ & 258 \\
\hline
\end{tabular}

The term hadits in the source language text refers to the sayings and tradition of Prophet Muhammad be peace upon him. In (9.a) the term hadiths which are plural is translated into The Prophet Muhammad as the center of hadiths. She puts the Prophet Muhammad as the active subject to the whole sentence replacing the term hadits. The translation technique is then modulation; the translator sees this context from different point of view that the whole content of hadits (the sayings and the deeds of Prophet Muhammad) is replaced by one part of it (Prophet Muhammad). In (9.b) the term hadits is put back in the target language text without any change either in the form or in the function by applying borrowing translation technique. There is not any explanation following the term. It is assumed that the translator let this be because the explanation about the term reveals in other part of the text. With the same translation technique, borrowing, the term hadits in (9.c) is used directly as the equivalence in the target language. The translator does not need to make anything as it is the subject of a definition about what the term is.

Table 10. Tajwid.

\begin{tabular}{|c|c|c|c|c|}
\hline No. & Source Language & Page & Target Language & Page \\
\hline \multicolumn{5}{|c|}{ Translation Techniques: Borrowing + Amplification + Generalization } \\
\hline \multirow{2}{*}{ 10.a } & "Bukan suluk tapi shunduq, pakai shad," jawab Raja dengan & 61 & "Not suluk, but shunduq, use shad,"answered Raja, correcting & 58 \\
\hline & tajwid yang sangat fasih & 1 & Said's pronunciation with fluent tajwid, Quran pronunciation. & 1 \\
\hline \multicolumn{5}{|c|}{ Translation Technique: Modulation } \\
\hline $10 . b$ & $\begin{array}{l}\text { Now, dibaca dengan berdengung panjang persis seperti dia } \\
\text { membaca mad panjang tiga harakat dalam ilmu tajwid. }\end{array}$ & 118 & $\begin{array}{l}\text { Now, he read with long vibration just as if he were reading Al- } \\
\text { Quran }\end{array}$ & 110 \\
\hline
\end{tabular}


The next Islamic term relating to Al-Quran discussed is tajwid. [14] Tajwid (tajweed) is recitation of the Holy Qur'an with precise articulation and exact intonation. The use of the term tajwid in (10.a) is related to the pronunciation of some letters in Al-Quran. The sentence implies the meaning that Raja does not just respond to the utterance spoken by Said (the characters of Negeri Lima Menara) but also corrects the false pronunciation in a fluent way as regulated by tajwid, the Quran pronunciation. There are several translation techniques involved in the target language. When tajwid is transferred directly to the target language, the translator uses borrowing translation technique. When it is followed with a short description, Qur'an pronunciation, by generalizing what tajwid is, the translator uses generalization translation technique. When the translator adds the implicit information relating to Raja's answer that actually Raja is correcting Said's pronunciation, the translator uses amplification translation technique. It is assumed by these equivalences that the translator would like the readership of the target language get the whole idea of what tajwid is so they will get familiar with the term in Islam religion relating to how letters are pronounced in Al-Quran.

There are two translation phenomena in (10.b) relating to the term tajwid when it is translated into the target language. The first one is considered seen from different understanding, it is when the word berdengung 'nasalized' as a part of tajwid is translated into vibration. The word berdengung in AlQuran is produced by a process of nasalizing (gunnah) not by the process of vibrating. In fact, in Al-Quran there is no sound production which is made by vibrating. Any different way of pronouncing even to one single letter will lead to a mistake, it cannot be tolerated as this is the Holy Quran, the guidance for Muslims, the guidance for all human kinds. By this research it is clarified that berdengung is not equal to vibration. The second phenomenon involves one of the translation technique called modulation. It is when the clause persis seperti dia membaca mad panjang tiga harakat dalam ilmu tajwid 'exactly like he is reading mad three beats long in tajwid rules' is translated into as if he were reading AlQuran. The translator neutralizes the expression mad panjang tiga harakat dalam ilmu tajwid into Al-Quran through modulation (part for the whole) technique. This can be accepted as mad panjang tiga harakat dalam ilmu tajwid is one of the rules on how to read Al-Quran and the expression of ilmu tajwid deals with Al-Quran pronunciation. It is assumed that from the equivalence chosen, the translator would like to inform the readership of the target language that the long nasalization is a part of sound production in AlQuran.

Table 11. Khatam.

\begin{tabular}{|c|c|c|c|c|}
\hline No. & Source Language & Page & Target Language & Page \\
\hline \multicolumn{5}{|c|}{ Translation Technique: Borrowing } \\
\hline 11.a & $\begin{array}{l}\text {...khatam Al-Quran di madrasah, sampai kelulusan } \\
\text { TK kedua adikku }\end{array}$ & 161 & $\begin{array}{l}\text {...khatam Al-Quran at the madrasah, and my two younger } \\
\text { siblings“ kindergarten graduation. }\end{array}$ & 151 \\
\hline \multicolumn{5}{|c|}{ Translation Technique: Generalization } \\
\hline 11.b & "Keduanya sudah saya khatam 2-3 kali." "Khatam?" & 265 & I have completed both two or three times. Completed? & 249 \\
\hline
\end{tabular}

The term khatam is usually used to refer to the completion of reciting Al-Quran from the first surah 'a chapter in the Holy Quran' until the end, the 114th surah. In (11.a) the translator just uses the term back in the target language as a borrowing. No explanation provided there. However in (11.b) the translator does not use this borrowing translation technique anymore. The term is used by the character of the novel to refer not only to Al Quran but also to a dictionary. He would like to emphasize that he had read all the content of the dictionary from the beginning until the end. By generalizing the meaning of khatam using generalization translation technique, the term khatam in this context is translated into 'have completed'. It is of equal value both in the form as well as in the function as what it is discussed there is not the Holy Qur'an but a dictionary.

\section{Conclusion}

Based on the discussion it can be concluded that Islamic terms which are repeatedly used are not always translated into the same equivalences by using the same translation techniques. It turns out that the problem of equivalence does not always have something to do with the meaning. It involves other things too like context. Sometimes the same exact term when used in a different context may have different meaning.

The repeated Islamic terms used for this research are of two kinds; the Islamic terms relating to praying and Islamic terms relating to Al-Quran. By this research it can be seen that some Islamic terms which are repeatedly used are translated using the same translation techniques but having different equivalences. Some others which are repeatedly used are translated by using the different translation technique and having different equivalences. And there is one Islamic term which is repeatedly used is translated using the same translation technique and having the same equivalence. It can be seen as well that the translation technique which is more frequently used is borrowing.

Regarding to the nature of equivalence, there are three Islamic terms which are seen differently by the translator; shalat berjamaah, tahajjud, and a part of tajwid, called dengung. By this research it is clarified that the equivalence for shalat berjamaah in data (2.a) is not limited to the Friday congregational prayer together. The term berjamaah in shalat berjamaah can be congregational and communal as well and Friday congregational prayer is only a part of shalat 
berjamaah. The next is Tahajjud in (8.b) when the writer expresses "...menambah ibadah dengan shalat sunnat Tahajjud" 'adding worship by performing shallat Sunna Tahajjud' is actually the ibadah 'worship' which is added by performing Tahajjud prayer. not adding the Tahajjud prayer. The translator translates this into 'add an additional night prayer called Sunna Tahajjud'. The third case is when a part of tajwid called dengung is translated into vibration. Dengung (called gunnah) in Tajwid is not pronounced by vibrating but by nasalizing.

When dealing with the use of repeated similar Islamic terms in the translation, it is highly recommended that a translator uses borrowing technique + generalization or borrowing + description especially at the first occurrence of it in the text to avoid confusion, a different understanding about the Islamic terms or misinterpretation.

\section{References}

[1] C. R. Nida, Eugene A \& Taber, HELPS FOR TRANSLATORS THE THEORY AND PRACTICE OF TRANSLATION, Volume VII. Leiden: E. J. Brill, 1982.

[2] A. Pym, Exploring Translation Theories, 2nd ed. Routledge Taylor and Francis Group, 2014.

[3] L. Molina and A. Hurtado Albir, "Translation Techniques Revisited: A Dynamic and Functionalist Approach," Meta J. des traducteurs, vol. 47, no. 4, p. 498, 2002.
[4] Newmark, A Textbook of Translation, 1st ed. Prentice Hall International (UK) Ltd, 1988.

[5] S. Hariyanto, Website Translation (with special reference to English-Indonesian language pair), 2nd ed. Malang, Indonesia: Penerbit Inspira, 2015.

[6] M. Farkhan, "Translation Strategies of Islamic Terms In Indonesian-English Research Papers," in Advances in Social Science, Education and Humanities Research (ASSEHR), 2018, vol. 154, no. Icclas 2017, pp. 63-66.

[7] S. Hassan, "Islamic religious terms in English - Translation vs. Transliteration in Ezzeddin Ibrahim and Denys JohnsonDavies' translation of An-Nawawis Forty Hadiths," Transl. Interpret., vol. 8, no. 1, pp. 117-132, 2016.

[8] M. Baker, In Other Words: A coursebook on translation, second edition., 3rd ed. Routledge Taylor and Francis Group, 2011.

[9] D. Hamdani, "The Quest for Indonesian Islam:," The Australian National University, 2007.

[10] Erlina, "Translation Studies: Basic Guidelines for Students of Translation Major,” vol. 1, no. August, p. 29, 2016.

[11] M. George, Elements of Library Research. Princeton University Press, 2008.

[12] C. R. Kothari, Research Methodology_ Methods and Techniques. Jaipur: New Age International Püblishers, 2004.

[13] A. J. Nathif, KITAB AL-SALAAT (The Book of Prayer). pdf. Riyadh: Cooperative Office for Call and Guidance, 1991.

[14] A. M. Zanaty, Glossary of (Islamic Terms) English - Arabic. 